\title{
IS BARTH GEREFORMEERD?
}

Daar het 'n tydjie gelede 'n boek verskyn van dr. G. C. van Niftrik in Nederland. Die boek is getitel "Een beroerder Israëls" en dit behandel die teologie van Barth. Alhoewel Van Niftrik op enkele punte van Barth verskil, is hy 'n bewonderaar van hom en vergelyk hy hierdie geleerde met Elia van ouds, wat deur koning Agab 'n „beroerder van Israel" genoem is.

Ons wil uit die boek enkele aspekte van Barth se beskouinge bespreek en hoop dan dat dit duidelik sal word dat hierdie 20ste-eeuse „beroerder Israëls" wel 'n beroerder is, soos min tevore, maar ongelukkig nie 'n Elia nie en ook nie 'n Gereformeerde nie. Ons kan dan ook geensins met Van Niftrik saamstem nie as hy sê: „Barth's theologie is een vernieuwing van het reformatorisch denken: een doortrekken van de lijnen, die Luther en Calvijn hebben uitgestippeld. (p. 23).

\section{GODSBESKOUING.}

Van Niftrik wys daarop dat volgens Bath God die Gans-Andere, die Onbekende is. Daar is 'n absolute, kwalitatiewe verskil tussen God en die mens (wêreld). God is ,nooit en nimmer identiek met wat wij God noemen, als God beleven, vermoeden en aanbidden" (p. 42). God is dic 
Verborge God, Deus absconditus. En ook in sy openbaring bly $\mathrm{Hy}$ verborge en word nooit die bekende nie.

Hierin kom dus o.i. die idealistiese agtergrond van Barth uit. Sy uitgangspunt is die Kantiaanse tweespalt tussen die noemenale en die fenomenale. Daar is cenvoudig geen oorgang of aansluiting tussen ons en God nie. Die twee terme sluit mekaar volkome uit. Die mens bly steeds in die wêreld bevange en kan nic vandaaruit kontak met die goddelike en ewige verkry nie. Wat hy van God weet of uitspreek is maar sy eie gedagte of opvatting of idee, maar het nooit betrekking op die wese van die lewende God Self nie. Waar God Homself aan die mens openbaar, word daardie openbaring nie 'n stuk menslike kennis nie, maar bly dit in Christus verborge.

\section{RELIGIE.}

Van Niftrik gee Barth se opvatting oor religie as volg: „Religie is de poging van den mens om van den mens uit een toren te bouwen, welks opperste in den hemel moet reiken. Hy bereikt dien hemel nooit." Religie is in sy wese eigenlik sonde omdat die mens daarin homself van God af distansieer en homself teenoor God stel (p. 47,48). In die religie sterf ons aan God. Dit is die „Krankheit zum Tode." En dan moet ons goed verstaan dat hierdie opvatting van Barth alle religie, ook die Christelike, omvat.

Vir Barth is religie dus eintlik die hoogste vorm van sonde, van menslike hubris en eiegeregtigheid. Die mens wil in en deur sy religie homself regverdig en tot God uitstyg. Hierin is wel 'n waardevolle element, insoverre Barth die Fariseïese werkheiligheid (valse vroomheid) kragtig en skerp weerstaan. Daar is seker altyd die gevaar by die religie, ja hier juis sterker as op enige ander punt, dat die mens homself kan wil verhef. Maar teenoor Barth moet ons dan tog stel dat die Christelike godsdiens nie saam met alle menslike vorme van religie eenvoudig as een stuk sonde weggewerp moet word nie. Ons moet nie die kind saam met die badwater weggooi nie. Religie beteken Godverbondenheid en eis dat ons God moet eer en dien met gedagtes, woorde en dade, ja dat ons ganse lewe aan God gewy moet word.

\section{DIE HEILIGE SKRIF.}

Van die Gereformeerde (Protestantse) opvatting van Skrifinspirasie praat die Barthiane smalend as 'n gevangeneming van Gods Woord in die Bybel en van die Bybel as 'n Boekpous.. „Ook het Protestantisme heeft op zijn wijze God en Zijn Openbaring gevangen willen nemen. Het Protestantisme heeft deze insluiting beproefd door zijn leer over den Bijbel. Het heeft het levende en vrije, souvereine Woord Gods indentiek verklaard 
met elken zin, elke woord, elke punt en elke komma van het geïnspireerde bijbelboek. Het Protestantisme heeft het geloof laten overgaan in christelijkheid en de boodschap Gods in een levens- en wêreldbeschouwing" (p. 53). Van Niftrik voeg hieraan toe dat as ons dan tog 'n absoluut gesagvolle instansie moet hê, ons dan maar liewer na die RoomsKatolisisme kan oorgaan. Teenoor die Roomse is ons maar dillettante met ons onfeilbare Bybel.

Daarteenoor sê Van Niftrik dat ons daaraan herinner moet word dat die Bybel 'n menslike boek is en so nie, dan lei ons Bybelopvatting ons tot afgodery en beeldediens. Die Bybel word dan 'n afgod. Die dialektiese teologie staan dus vir die Skrifkrtiek prinsipieel oop. Die Bybel, as 'n stuk mensewerk, dra al die kenmerke van menslike beperktheid en feilbaarheid en is nie Gods Woord, bevat dit selfs nie eens nie, maar is net 'n bloot menslike getuienis, wat heenwys na die Woord Gods wat daarin verborge is en bly. Hieruit moet dit vir ons duidelik wees wat 'n gapende afgrond daar tussen ons opvatting en diè van die Barthiane is. 'n Mens verbaas jou dat daar in ons land so met vuur gespeel word deur teoloẻ wat probeer om Barth te propageer as die apostel van die Geref. godsdiens.

\section{HISTORIE EN OPENBARING.}

Vir Barth is die openbaring van God wel geskiedenis, maar die geskiedenis is nooit openbaring nie (p. 31). Hier staan Barth lynreg teenoor die historisering van die Goddelike openbaring deur identifikasie daarvan met die wêreldgeskiedenis, soos o.a. sterk deur Troeltsch voorgestaan is. Bygevolg wys Barth ook elke vorm van algemene openbaring van God in die natuur, die geskiedenis en die menslike rede (gewete) af. Van Niftrik wys daarop dat vir sover Jesus Christus in ons geskiedenis ingegaan het en daaraan deel gehad het, Hy God nie daarin geopenbaar het nie. „Voorzoover Jezus tot de menselijke historie behoort, gaat ook over Zijn leven de crisis, het oordeel Gods" (p. 46). Jesus, die historiese mens, moes sterwe sodat die Christus in Hom kon opstaan. Die oordeel Gods gaan oor alle historiese as sodanig. Die geskiedenis kan, sonder om self openbaring te wees, getuig van God se openbaring en word dan gekwalifiseerde geskiedenis. Geskiedenis is vir Barth ongekwalifiseerde chaos. "Als de geschiedenis van God getuigt, dan niet door haar zin, maar door haar onzin," (p. 89).

Hierteenoor handhaaf ons die geskiedenisbeskouing, waarvolgens God Hom in alles openbaar. Art 2 van ons Nederlandse Geloofsbelydenis toon duidelik aan wat ons opvatting is. Die wêreld is nie van God verlate, ten dode gerig en aan Satan oorgegee nie. God spreek in en deur die werke van sy hande sowel in die natuur as in die geskiedenis en laat 
Homself nooit onbetuig nie. Die geskiedenis word deur Christus nie beëindig en begrawe nie, maar tot sy glorie en hemelse bestemming gelei. Die verlossing van die wêreld is herskepping van wat verlore was en nie 'n nuwe skepping nie. Die Koninkryk van God ontstaan wel nie deur inherente groei en ontwikkeling van die immanente kragte van hierdie wêreld nie, maar is tog wel 'n glorieryke deurvoering en voltooiing, deur die dood heen, van wat God in sy skepping gelê en gegee het, deur die opstanding van Christus. Die hele geskiedenis is vol van God se kragtige teenwoordigheid wat die skynbare chaos tot hemelse orde en harmonic omskep en dit voltooi in die heerlike Koninkryk van die Hemele.

\section{DIE LEER VAN DIE UITVERKIESING.}

Van Niftrik verduidelik dat Barth die uitverkiesingsleer radikaal anders verstaan as wat die Hervormers dit gedoen het. Volgens Barth is alleen Christus Jesus uitverkies. In Hom is alle mense verworpe én uitverkore. „Er zijn geen verkorenen en verworpenen, zoals er blanken en zwarten, mannen en vrouwen zijn!! Gods verkiezing gaat uit naar één mens, den mens Jezus Christus" ( $p .135$ ). God het Jakob nie uitverkies en Esau verwerp nie, maar Hy verwerp elke mens, as Esau, en verkies elke mens, as Jakob. Verwerping is nie wesenlike verwerping nie, maar eintlik maar net die onmoontlike moontlikheid (p. 137). Die predestinasie lê nie vas in God se Raad as sodanig nie, maar is alleen in Christus werklikheid. Anders word God 'n gevangene van sy eie dekreet. Van Niftrik sê dat Calvyn die fout gemaak het om die uitverkiesingsleer te rasionaliseer en dit ' $n$ kwessie van getalle te maak. Calvyn sou in sy uitverkiesingsleer nie met Christus gereken het nie en 'n verkiesing (verwerping) buite Christus om geleer het. Daarenteen sou Barth dan nou die predestinasie in Christus gefundeer en dit also van alle spekulatiewe elemente verlos het. En Van Niftrik kom dan tot die slotsom dat die predestinasie-leer eigeniik net maar beteken dat God onveranderlik is in sy trou en dat $\mathrm{Hy}$ dus altyd verkies wat Hy verwerp het. „Daarom is er een heilige veránderlijkheid Gods" (p. 148). Uitverkiesing en verwerping is eintlik maar net aanduiding van God se onveranderlike liefde en genade teenoor die sondaar. En uit dit alles volg dan dat Christus alle mense red, 'n Christus pro omnibus is, alhoewel Van Niftrik versigtig is om dit nie so skerp te stel nie en altyd nog praat van die onmoontlike moontlikheid dat sommige mense kan verlore gaan.

Ons sien egter hieruit waartoe die dialektiese Godsbeskouing lei. As die ganse skepping assodanig buite God in die graf wegsink, dan moet daar 'n herstel van alle dinge in Christus wees, apokatastasis toon pantoon. Omdat daar nie 'n wesenlike doodslyn deur die wêreld heen loop, n.l. die sonde wat skeiding maak tussen regverdiges en onregverdiges 
nie, daarom moet daar in God self ' $n$ veranderlikheid geponeer word, waardeur $\mathrm{Hy}$ in die een oomblik verwerp wat $\mathrm{Hy}$ net in die volgende oomblik (nee, in dieselfde oomblik) verkies. Die God van die Barthiaanse filosowe is 'n verandelike wese en het geen vaste, ewige wil nie, soos Occam reeds geleer het.

\section{BARTH EN DIE ETIEK.}

Daar is nog talle van belangrike punte wat ons sou kon bespreek, bv. Barth se verwerping van die kinderdoop, sy valse versoeningsleer, sy independentistiese (indiwidualistiese) kerkbegrip, sy spekulatiewe esgatologie ensomeer.

Maar ons wil ons ten slotte nog net bepaal by sy eksistensialistiese sedeleer of etiek. Daarmee bedoel ons nie dat Barth 'n eksistensialis is soos Sartre nie. Maar, soos ons sal probeer antoon, Barth se etiek het geen vaste beginsels of grondslae nie en is eksistensieel in dié sin dat die sedelike plig en roeping afhanklik gemaak word van die eksistensiële situasie, die hic et nunc, waarin die mens hom bevind en waarin hy met God se openbaring gekonfronteer word.

In die eerste plek dan is en bly die-mens, ook die wedergebore mens, sondaar in sy ganse bestaan hier op aarde. "Ook na bekering en wedergreboorte zijn en blijven wij mensen, wier leven één stuk zonde isóók hun geestelijk en kerkelijk leven,--mensen, die alleen maar leven kunnen van genade, d.i. van de rechtvaardiging van den in zichzelf goddeloze, d.i. van de vreemde vrijspraak" (p. 21).

Die heiligheid wat ons as gelowiges besit, besit ons enkel en alleen in Christus en niks in onsself nie. „Deze gerechtvaardigde en geheiligde, veranderde en vernieuwde mens heeft geen eigen nieuwe werkelijkheid en nieuwe kwaliteiten, zodat hij nu als de nieuwe mens voorwerp van een apart onderzoek zou kunnen worden" (p. 97).

Die Wet van God (10 Gebooie) is dan ook g'n beginsels, waarvolgens ons ons lewe moet inrig nie, maar enkel paradigma, voorbeeld en trouens ook afbakening. Dit gee net die grense aan waarbinne ons ons moet beweeg.

Verder wys Van Niftrik daarop dat volgens Barth daar by natuurlike mens totaal niks van die beeld Gods oorgebly het, waarby God sou kan aanknoop in sy besondere openbaring nie. Daar is nie soiets soos klein vonkies of oorblyfsels van natuurlike Godskennis, die sensus divinitatis van Calvyn nie. Daarom het Barth gebreek met Brunner en Gogarten, wat vir hul Etiek 'n algemeen menslike grondslag, 'n antropologiese onderbou aanvaar (p. 105). Dit gaan by God nie om ,nieuwschepping" nie. „God trekt Zijn gebouw niet op op het substraat van een menselijk kennen en gevoelen." 
So kan ons dan duidelik sien hoe wyd die kloof tussen ons en Barth gaap, ook op etiese gebied. Barth wil van geen Christelike beginsels weet nie. Sy Etiek bly absoluut vaag en onbepaald. Dit is selfs nie duidelik hoedat daar enige grense kan wees waarbinne ons moet handel nie. Immers, dan het ons tog maar weer 'n beginsel wat ons bind, hoe wyd en algemeen dit ook mag wees. God is tog aan Homself getrou en sy Wil onveranderlik, soos Hyself. Ons kan gladnie met Van Niftrik saamstem nie as hy sê: Gods geboden zijn elken morgen nieuw. Gods Woord, Gods Wet is Gods dáád, Gods spreken (werkwoord!) hier en nu in de concrete situatie, waarin wij ons bevinden" (p. 119).

Barth verwerp die „analogia entis"-leer van die Roomse Kerk. Daar is geen verwantskap, ooreenkoms tussen God en die mens as sy beelddraer nie. Genade is enkel justitia forensis en geen „Dinglichkeit” nie.

Alhoewel ons genade nie materieel opvat, soos die Roomse nie, tog glo ons dat genade nie bokant die mens bly sweef nie, maar hom inderdaad aangryp en vernuut na die ewebeeld van God. Die gelowige is in Christus en Christus in hom en daarom wandel hy in nuwigheid van lewe. Behorende aan Christus is hy deur Christus tot alle dinge in staat. $\mathrm{Hy}$ is die lig van die wêreld en 'n soutende sout in die lewe. Hy is nie 'n slaaf van „beginsels" nie, maar leef uit die één grondbeginsel van gehoorsaamheid aan die wil van God, soos uitgedruk in God se heilige Wet. En dit doen hy nie uit beginselverheerliking nie, maar uit liefde en dankbaarheid teenoor Christus. Dit maak van hom 'n koersvaste, daadkragtige, blymoedige en getroue stryder vir die eer van God op elke terrein van die lewe. Hy beleef sy Christenskap nou en hier, altyd en oral.

Brakpan. S. J. v.d. WALT. 